\title{
Electrodialytic removal of heavy metals and chloride from municipal solid waste incineration fly ash and air pollution control residue in suspension - test of a new two compartment experimental cell
}

Kirkelund, Gunvor Marie; Magro, Cátia; Guedes, Paula; Jensen, Pernille Erland; Ribeiro, Alexandra B.; Ottosen, Lisbeth M.

\section{Published in:}

Electrochimica Acta

Link to article, DOI:

10.1016/j.electacta.2015.03.192

Publication date:

2015

Document Version

Peer reviewed version

Link back to DTU Orbit

\section{Citation (APA):}

Kirkelund, G. M., Magro, C., Guedes, P., Jensen, P. E., Ribeiro, A. B., \& Ottosen, L. M. (2015). Electrodialytic removal of heavy metals and chloride from municipal solid waste incineration fly ash and air pollution control residue in suspension - test of a new two compartment experimental cell. Electrochimica Acta, 181, 73-81. https://doi.org/10.1016/j.electacta.2015.03.192

\section{General rights}

Copyright and moral rights for the publications made accessible in the public portal are retained by the authors and/or other copyright owners and it is a condition of accessing publications that users recognise and abide by the legal requirements associated with these rights.

- Users may download and print one copy of any publication from the public portal for the purpose of private study or research.

- You may not further distribute the material or use it for any profit-making activity or commercial gain

- You may freely distribute the URL identifying the publication in the public portal 


\section{Highlights}

- Acidification of residue suspension is faster in the 2 compartment cell

- $\mathrm{pH}$ in residue suspension is the determining factor for remediation success

- Leaching limiting values can be met for fly ash after electrodialytic remediation 


\title{
Electrodialytic removal of heavy metals and chloride from municipal solid waste incineration fly ash and air pollution control residue in suspension - test of a new two compartment experimental cell
}

\author{
Gunvor M. Kirkelund ${ }^{a^{*}}$, Cátia Magro ${ }^{a b}$, Paula Guedes ${ }^{b}$, Pernille E. Jensen ${ }^{a}$, Alexandra B. \\ Ribeiro $^{\text {b }}$, Lisbeth M. Ottosen ${ }^{\text {a }}$ \\ ${ }^{a}$ Department of Civil Engineering, Brovej, Technical University of Denmark, DK-2800 Kgs. \\ Lyngby, Denmark \\ ${ }^{\mathrm{b}}$ CENSE, Departamento de Ciências e Engenharia do Ambiente, Faculdade de Ciências e \\ Tecnologia, Universidade Nova de Lisboa, Campus de Caparica,2829-516 Caparica, Portugal
}

*Corresponding author: gunki@byg.dtu.dk, Tel.: + 4545251730

\begin{abstract}
Municipal solid waste incineration (MSWI) residues such as fly ash and air pollution control (APC) residues are classified as hazardous waste and disposed of, although they contain potential resources. The most problematic elements in MSWI residues are leachable heavy metals and salts. For reuse of MSWI residues in for instance concrete, the aim of remediation should be reduction of the heavy metal leaching, while at the same time keeping the alkaline $\mathrm{pH}$, so the residue can replace cement. In this study a MSWI residues were subjected to electrodialytic remediation under various experimental conditions. Also a newly developed 2 compartment experimental cell was tested. The results show that the $\mathrm{pH}$ development in the MSWI residue suspension depended on the type of MSWI residue and the experimental cell type. The acidification of the suspension occurred earlier when using the 2 compartment setup and the acidification of the fly ash occurred earlier than for the APC residue but the highest removal was seen with the 3 compartment cell. The lowest final $\mathrm{pH}$ for the fly ash and APC residue was 6.4 and 10.9, respectively. The results showed that the leaching of $\mathrm{Cd}, \mathrm{Cu}, \mathrm{Pb}$ and $\mathrm{Zn}$ was reduced compared to the initial heavy metal leaching except when the $\mathrm{pH}$ was reduced to a level below 8 for the fly ash. On the other hand, $\mathrm{Cr}$ leaching increased by the electrodialytic treatment. $\mathrm{Cl}$ leaching from the MSWI residues was less dependent on experimental conditions and was reduced in all experiments compared to the initial levels.
\end{abstract}


Keywords: electrokinetic remediation, fly ash, leaching, heavy metal, chloride

Nomenclature:

APC - Air pollution control

EDR - Electrodialytic remediation

MSW - Municipal solid waste

MSWI - Municipal solid waste incineration

I/S REFA - Waste-to-energy incineration plant, semi-dry APC system

SD - APC residue from REFA

I/S Vestforbrænding - Waste-to-energy incineration plant, wet APC system

W - Fly ash from Vestforbrænding

\section{Introduction}

Incineration of municipal solid waste (MSW) is commonly used to gain energy and hygenize and minimize the amount of solid waste. The residues from MSWI are flue gas, bottom ash and fly ash or air pollution control (APC) residues depending on the air pollution control system of the incineration plant. In Denmark, all MSWI plants have air pollution control system to minimize the emissions of acidic gases and dioxins. Fly ash is typically removed in electrofilters or cyclones, while the air pollution control process can be either a dry/semidry (injection of lime in dry form or in a slurry to the flue gas) or wet (flue gas is subjected to a scrubber after removal of fly ash). Either treatment method, the resulting residues are classified as hazardous waste due to the high content of contaminants and salts. The main management system of MSWI residues is disposal in hazardous waste facilities [1].

The electrodialytic remediation (EDR) method has been used to remove mainly heavy metals from particulate waste materials such as soil, harbor sediment and different ashes (biomass, sewage slugde, MSW) [2-6]. Ions electromigrate in the applied electric field during EDR and to maximize their desorption and availability, ionic forms are essential for the process. To reuse the MSWI 
residues as secondary resources, removal of contaminants and salts is necessary to reduce their toxicity. EDR treated APC residue has indicated potential for substitution of cement in mortar [7], but improvements in reduction of heavy metal leaching and chloride content is still needed.

The removal of heavy metals from MSWI fly ashes using EDR was first applied in a conventional stationary EDR cell with the fly ash saturated with water or desorbing agent [8]. These initial experiments resulted in severe precipitations in the electrolytes, on the ion exchange membranes and in the fly ash. Furthermore, poor control of the $\mathrm{pH}$ both in the electrolytes and in the fly ash itself, revealed the need to suspend the fly ash matrix in the cell. Pedersen et al. [9] introduced a stirrer in the suspension cell compartment II, Fig. 1a. After the introduction of the stirrer, several studies about EDR of fly ash were made, especially with the use of assisting agents to further enhance the remediation process. Ammonium citrate and gluconate were mostly used as assisting agents, with the purpose of enhancing solubilisation of the heavy metals and form stable charged complexes that could be removed in the electric field and at the same time keeping the alkaline $\mathrm{pH}$ in the fly ash. Allowing acidification of the ash during EDR means dissolution of a high quantity of the ash and is thus not an energy efficient separation of the ash and heavy metals. Ammonium citrate as assisting agent was used in EDR of fly ash and these electrodialytic experiments showed higher removals than just by batch extractions and up to $20 \% \mathrm{Cr}, 60 \% \mathrm{Cd}, 6 \% \mathrm{~Pb}, 40 \% \mathrm{Zn}$ and $60 \% \mathrm{Cu}$ were removed after 2 weeks of remediation [9]. When increasing the remediation time, even higher removals could be obtained, with the lowest still for $\mathrm{Cr}$ and $\mathrm{Pb}$ [10]. Gluconate was tested as assisting agent for APC residue and high desorption of the metals was seen in batch extraction but much lower removal was seen in EDR experiments, probably due to the size of the metal-gluconate complexes that could not pass the ion exchange membranes [11]. EDR with gluconate was later improved with pre-treatment of the APC residue before EDR, such that $82 \%$ $\mathrm{Cd}, 10 \% \mathrm{~Pb}, 63 \% \mathrm{Zn}$ and $22 \% \mathrm{Cu}$ were removed after 2 weeks of remediation [6]. One major drawback of using assisting agents is however the significant matrix changes observed both in the mineralogy and the morphology of the fly ash [12] which could hinder reuse. The addition of assisting agents also adds an extra cost to the process.

Suspending the fly ash in distilled water during EDR also results in removal of heavy metals [9]. The removal process in this case is dependent on the solubility and release of the heavy metals from the fly ash particles at high pH. In the 3 compartment cell (Fig. 1 a), acidification of the suspension is caused by water splitting at the anion exchange membrane and proton leakage through the anion 
exchange membrane [13, 14,], which leads to enhanced removal of heavy metals during EDR. Some of the few experiment of EDR with fly ash suspended in distilled water in the stirred set-up, showed varying removal results of $\mathrm{Cd}, \mathrm{Cr}, \mathrm{Cu}, \mathrm{Pb}$ and $\mathrm{Zn}$ and indicate that the removal occurs both towards the anolyte and the catholyte $[9,15]$. The removal towards the anode can occur due to the complexation between divalent metal ions and chloride to form stable negatively charged complexes $\left(\mathrm{MeCl}_{3}{ }^{-}, \mathrm{MeCl}_{4}{ }^{2-}\right)$ and for $\mathrm{Cr}$ also the presence of negatively charged $\mathrm{Cr}$ (VI) ions.

Recently, a new cell design was developed and patented for EDR of suspensions, where the anode is placed directly in the material suspension and thus combines the anolyte and the suspension compartment into compartment I, Fig. 1b $[16,17]$. This new cell design promotes a more direct acidification of the suspension, where all the produced $\mathrm{H}^{+}$ions from the electrolysis at the anode $\left(2 \mathrm{H}_{2} \mathrm{O} \rightarrow \mathrm{O}_{2}(\mathrm{~g})+4 \mathrm{H}^{+}+4 \mathrm{e}^{-}\right)$will be supplied directly in the suspension. Anions are in the 3 compartment cell removed to the anolyte and in the case of $\mathrm{Cl}^{-}$an oxidation to $\mathrm{Cl}_{2}(\mathrm{~g})$ will occur at the anode. In the 2 compartment cell, it is expected that the oxidation and subsequent removal could be faster, since the electrode is in direct contact with the suspension. Contrarily, if the heavy metals are present as anions in the 2 compartment cell, they will not be removed from the suspension.

The purpose of this study was to investigate 1) the remediation of two types of MSWI residue (fly ash and APC residue) for heavy metals and chloride according to several different experimental variables and 2) to which extent the new 2-compartment cell could improve the remediation of heavy metals and chloride from MSWI residues. The aim was to obtain a stable residue in the sense that it is not leaching heavy metals and chlorides above the Danish limiting values for reuse of waste in constructions after the treatment.

\section{Materials and methods}

\subsection{MSWI residues}

Two types of MSWI residues were used in this study from Danish municipal waste incineration plants:

- SD: APC residue collected after a semi-dry process after the injection of slaked lime and activated carbon from I/S REFA, where 3,000 tons APC residue is produced annually. 
- W: A fly ash sample collected prior to the neutralization of acidic components by a wet scrubber process from I/S Vestforbrænding, where 15,000 tons of APC residues, including fly ash is produced annually.

\subsection{Analytical methods}

The MSWI residues characterization and extraction experiments were carried out using dried residue at $105^{\circ} \mathrm{C}$ for $24 \mathrm{~h}$ and triplicates were made for the analysis. Total concentration of $\mathrm{Cd}, \mathrm{Cr}$, $\mathrm{Cu}, \mathrm{Pb}$ and $\mathrm{Zn}$ in the MSWI residues were measured by Inductively Coupled Plasma - Optical Emission Spectrometry (ICP-OES), after pre-treatment according to DS 259 [18], in which $1 \mathrm{~g}$ of MSWI residue and $20 \mathrm{~mL}(1: 1) \mathrm{HNO}_{3}$ were heated at $200 \mathrm{kPa}\left(120^{\circ} \mathrm{C}\right)$ for $30 \mathrm{~min}$. After digestion, the samples were vacuum filtered through a $0.45 \mu \mathrm{m}$ filter and diluted till $100 \mathrm{~mL}$. The units used in this paper are $\mathrm{mg} / \mathrm{kg}$ in dry matter for the concentration.

The $\mathrm{pH}$ in the MSWI residues was measured with a Radiometer $\mathrm{pH}$-electrode in $1 \mathrm{M} \mathrm{KCl}$ at $\mathrm{L} / \mathrm{S}$ ratio of 2.5 and in deionised water at liquid to solid $(\mathrm{L} / \mathrm{S})$ ratio of 5 , after $1 \mathrm{~h}$ of agitation at 190 $\mathrm{rpm}$. The electrical conductivity was measured at the same time as the $\mathrm{pH}$ with deionised water, with a Radiometer Analytic electrode. Water content was measured as weight loss after $24 \mathrm{~h}$ at 105 ${ }^{\circ} \mathrm{C}$ (calculated as weight loss over the weight of the wet sample). Loss on ignition (LOI) was calculated as weight loss after heating for $30 \mathrm{~min}$ at $550{ }^{\circ} \mathrm{C}$. Water solubility was made by suspending $100 \mathrm{~g}$ MSWI residue in $500 \mathrm{~mL}$ deionised water and agitate for $1 \mathrm{~min}$. After settling, the water was decanted and another $500 \mathrm{~mL}$ deionised water were added. This was repeated three times to ensure that the MSWI residues were properly washed. The suspension was then filtered thought a $0.165 \mu \mathrm{m}$ filter and the MSWI dried residue $\left(105^{\circ} \mathrm{C}\right)$ weighed. Carbonate content was determined using a Scheibler apparatus, where a standard curve was first performed using different $\mathrm{CaCO}_{3}$ contents combined with $\mathrm{HCl}$. The MSWI residues were mixed with $\mathrm{HCl}$ and then the $\mathrm{CaCO}_{3}$ concentration was determined.

Leaching tests on the MSWI residues were made according to DS/EN 12457-3 [19], with slight modifications. The L/S ratio was 2, mixing $10 \mathrm{~g}$ of MSWI residue and $20 \mathrm{~mL}$ deionised water. The suspension was shaken for $23 \mathrm{~h}$ on an end-over-shaker. The $\mathrm{pH}$ was measured in the suspension before vacuum filtration through a $0.45 \mu \mathrm{m}$ nucleo filter and the heavy metal concentrations in the filtrate were determined by ICP-OES. Water soluble chloride was determined by Ion 
Chromatography (IC) after extracting $10 \mathrm{~g}$ of MSWI residue with $50 \mathrm{~mL}$ of deionised water overnight.

Residue mineralogy was studied by X-ray powder diffraction (XRD), for identification of major crystalline phases. The instrument was a PANalytical X'Pert Pro operating at $45 \mathrm{kV}$ and $40 \mathrm{~mA}$ applying $\mathrm{Cu} \mathrm{K \alpha}$ radiation with a $2 \Theta \mathrm{X}^{\prime}$ Celerator detector. The samples were scanned in the range of 4-100 $2 \Theta$ within 2.5 hours. The diffractograms were interpreted using the ICDD PDF-4 database for minerals.

\subsection{Electrodialytic experiments}

Twenty-four EDR experiments were performed with the MSWI residues, according to the experimental conditions presented in Table 1. Twelve of them were performed in an ED cell with 3 compartments (Fig. 1a) and the other 12 were carried out in an ED cell with 2 compartments (Fig. 1b). All experiments were made with a suspension consisting of $350 \mathrm{~mL}$ of deionised water and 100 g MSWI residue, corresponding to an L/S ratio of 3.5.

The EDR cells were made of plastic with an internal diameter of $8 \mathrm{~cm}$ and the suspension compartment length was $10 \mathrm{~cm}$. Electrode compartments were separated from the suspension compartment by an anion-exchange membrane and/or a cation-exchange membrane from Ionics. The electrodes were platinum coated titanium. A power supply (Hewlett Packard E3612A) was used, maintaining a constant current of $5 \mathrm{~mA}$ or $50 \mathrm{~mA}$, corresponding to current densities of 0.1 $\mathrm{mA} / \mathrm{cm}^{2}$ or $1 \mathrm{~mA} / \mathrm{cm}^{2}$, respectively. The MSWI residue suspension was stirred in the suspension compartment by a flexible plastic flab, attached to a glass-stick and connected to an overhead stirrer (RW11 basic from IKA) with a rotation velocity rate of up to $2000 \mathrm{rpm}$.

The electrolytes were $0.01 \mathrm{M} \mathrm{NaNO}_{3}$ with $\mathrm{pH}$ adjusted to 2 with $\mathrm{HNO}_{3}$ (1:1). In the experiments with the 3 compartment cell, $500 \mathrm{~mL}$ of anolyte and $1000 \mathrm{~mL}$ of catholyte were used, while in the experiments with the 2 compartment cell, $500 \mathrm{~mL}$ of catholyte was used. The recirculation was made using "Pan World" magnetic pumps with a performance rate of $8 \mathrm{~L} / \mathrm{min}$. Voltage and electric current were read daily, whereas $\mathrm{pH}$ in the electrolytes and the $\mathrm{pH}$ and the electrical conductivity of the MSWI residue suspension were measured twice a day. $\mathrm{pH}$ in the electrolyte was adjusted with (1:1) $\mathrm{HNO}_{3}$, if $\mathrm{pH}>2$. 
At the end of the experiments the residue suspension was filtered before measurements for heavy metals and chloride. The dried MSWI residue was digested according to DS 259 and measured for heavy metals. The membranes and stirrer were soaked in $1 \mathrm{M} \mathrm{HNO}_{3}$ and the electrodes in $5 \mathrm{M}$ $\mathrm{HNO}_{3}$, to release precipitated metals. The obtained aqueous phase of the membranes, the stirrer, the electrodes and the electrolytes were all analysed for heavy metals $(\mathrm{Cd}, \mathrm{Cr}, \mathrm{Cu}, \mathrm{Pb}$ and $\mathrm{Zn})$ by ICPOES. The $\mathrm{pH}$, heavy metal and chloride leaching were also determined on the dry MSWI resides after the EDR experiments. The chloride concentrations in the liquid from the filtered MSWI residue suspension were measured according to DS 239 [20] by potentiometric titration with $\mathrm{AgNO}_{3}$.

\section{Results and discussion}

The chemical characteristics of the experimental MSWI residues are presented in Table 2, along with leaching limiting values. These values are Danish limiting values that represent the maximum allowed leaching values for reuse of waste materials in construction without restrictions $(\mathrm{C} 1)$ to restricted use (C3) [21]. Statistical analysis of the residue characteristics was carried out using GrafPad Prims 6 software. T-test was chosen because it is one-sided, since the objective was to compare each individual parameter. This test showed that the two types of MSWI residues are significantly different, with $99 \%$ and $95 \%$ confidence levels with some exceptions, such as water solubility and water content, due to the type of APC system.

The MSWI residues were rich in heavy metals and with significant leaching of both $\mathrm{Pb}$ and $\mathrm{Zn}$ above the limiting values. The MSWI residues were also characterized by having a large water solubility which is related to the high amount of soluble salts and minerals in MSWI residues. This finding is supported by the high electrical conductivity. Both MSWI residues are highly alkaline with $\mathrm{pH}$ above 12 and with high carbonate content, which was even higher for the APC residue than for the fly ash.

The low LOI obtained for the fly ash indicates a complete and efficient combustion during the incineration process, which means that a higher incineration temperature was achieved. Regarding the carbonate content, the APC residue presents a high value, which was expected as lime $(\mathrm{CaO})$ is used in the semidry gas cleaning process. Once $\mathrm{CaO}$ is exposed to moderate amounts of water, hydration occurs forming $\mathrm{Ca}(\mathrm{OH})_{2}$ that may later react with carbon dioxide from the ambient air to form calcium carbonate. 


\subsection{Electrodialytic remediation experiments}

The $\mathrm{pH}$ and conductivity in the MSWI residue suspensions during the EDR experiments is shown in Fig. 2, all measurements for each experimental series are displayed by the same notation. The applied currents of $5 \mathrm{~mA}$ and $50 \mathrm{~mA}$ were maintained constant during all experiments. The development of the $\mathrm{pH}$ and electrical conductivity was consistent within the same experiment, although the developments from the single experiments are not shown in Fig. 2, as the whole experimental series are displayed as one trend line. Thus, there are differences between each experiment series with the same conditions except the duration and these are mainly due to the heterogeneity of the MSWI residues. When $5 \mathrm{~mA}$ were applied, the voltage drop was $1.3-2.6 \mathrm{~V}$ and 1.3 - $5 \mathrm{~V}$ for the fly ash and APC residue, respectively. Similarly, the voltage drop when applying $50 \mathrm{~mA}$ was $2.5-7 \mathrm{~V}$ and $2.8-7.6 \mathrm{~V}$ for the fly ash and APC residue. The low voltage drop is a result of the high conductivity in the MSWI residue suspensions and the voltage levels were slightly lower for the 2 than the 3 compartment cell, especially for the fly ash experiments. However, the general energy consumption in a 3 compartment cell was found to be suspension $>$ membranes $>$ electrolytes [22]. This in addition to the cost of ion exchange membranes would favour the 2 compartment cell when upscaling of the method. The electrical conductivity in the EDR experiments with APC residue was higher than for the fly ash, mainly due to the higher chloride content in the APC residue. The overall trend seen from Fig. 2 is that the electrical conductivity decreased faster in the experiments with the 3 compartment cell than in the 2 compartment cell, and also to a lower level. In the 2 compartment cell, the lowest conductivity was obtained with the lowest current density, whereas in the 3 compartment cell the highest current density resulted in the lowest conductivity. This finding is due to the different setups, where the direct supply of $\mathrm{H}^{+}$ions into the suspension in the 2 compartment cell increases with current density, whereas there is increased removal of ions from the suspension in the 3 compartment cell with increasing current. As the $\mathrm{pH}$ in the residue suspension decreases, the result will be a higher dissolution of the residue. This is seen as a higher electrical conductivity in the experiments lasting 14 days. The electrical conductivity in the $\mathrm{W}-2-1$ experiments did not significantly decrease during the experimental duration, as $\mathrm{H}^{+}$ions are continuously being introduced to the suspension by the electrode reaction and continuous dissolution of residue at the decreasing $\mathrm{pH}$. Contrarily, for the $\mathrm{W}$ 3-1 experiments a different trend was seen, with an initial decreasing electrical conductivity until the $\mathrm{pH}$ decreases to where the main residue dissolution starts. It is expected that the electrical 
conductivity will continue to increase in both cell types, also for the 3 compartment cell, which was seen for soil [23] and sewage sludge ash [17] at longer duration.

Regarding $\mathrm{pH}$, the buffering capacity was much higher in the APC residue than in the fly ash, which is in accordance to what was expected from the carbonate content. It was also expected that the $\mathrm{pH}$ would generally decrease faster in the 2 compartment cell than in the 3 compartment cell. However, this was mainly seen for the fly ash at high current density, because these were the only experiments in which the buffering capacity was exceeded. Although after 12 days of remediation, the $\mathrm{pH}$ also decreased slightly in the APC residue suspension using the 2 compartment cell at high current density. In ash with a lower buffering capacity, e.g. sewage sludge ash, the $\mathrm{pH}$ decrease was significantly faster with the 2 compartment cell regardless of experimental conditions [17]. Furthermore, the higher buffering capacity observed by the slower $\mathrm{pH}$ decrease in the experiments with the APC residue could be due to the difference in mineralogy between the two residues, see Fig. 3. Especially by the presence of the main calcium phases; calcite $\left(\mathrm{CaCO}_{3}\right)$, portlandite $\left(\mathrm{Ca}(\mathrm{OH})_{2}\right)$, anhydrite $\left(\mathrm{CaSO}_{4}\right)$ and calcium hydroxychloride in the APC residue as opposed to only carbonate and anhydrite in the fly ash before remediation. In the APC residue, the Ca-containing minerals were also changed during the electrodialytic experiments, to also include bassinite $\left(\mathrm{CaSO}_{4} \bullet 0.5\left(\mathrm{H}_{2} \mathrm{O}\right)\right.$, thus keeping the high buffering capacity.

\subsection{Heavy metal removal}

The final $\mathrm{pH}$ measured in the residue and the removal of heavy metals, is shown in Table 3 , for the experiments lasting 14 days. The removal is defined as the amount of metal measured in the electrolytes and electrodes for the 3 compartment cell and in the catholyte and at the cathode for the 2 compartment cell. The highest total removals of metals were obtained in the experiments with the lowest final $\mathrm{pH}$ in the MSWI residue, as expected [15], and the metal removal was dependent on current density and type of MSWI residue, but less on the cell type. The removal was lower for the experiments lasting 3 and 7 days (results not shown), so increasing remediation time increased removal, due to the lower $\mathrm{pH}$. The $\mathrm{pH}$ given in Table 3 is measured after drying the residues and this residue $\mathrm{pH}$ was higher than the suspension $\mathrm{pH}$ shown in Fig. 2. Generally, the removals were below $5 \%$ for the heavy metals from the MSWI residues, with some clear exceptions; up to $61 \%$ 
$\mathrm{Cd}$ and $53 \% \mathrm{Zn}$ were removed from the fly ash and up to $66 \% \mathrm{~Pb}$ was removed from the APC residue.

In experiment W-3-0.1-14D the predominant removal was seen towards the anode. When the current density increased (W-3-1-14D) the speciation of the metals seemed to change, indicated by the lower removal towards the anode and $13 \% \mathrm{Cd}$ and $\mathrm{Zn}$ remained in the suspension compartment. This is probably caused by the decreasing $\mathrm{pH}$ and simultaneous removal of $\mathrm{Cl}$ in the suspension compartment [15] and also indicates uncharged species of $\mathrm{Cd}$ and $\mathrm{Zn}$. Increasing the current density in the 2 compartment cell for the fly ash, increased the amount of especially $\mathrm{Cd}, \mathrm{Cu}$ and $\mathrm{Zn}$ in the suspension compartment, but only increased the removal of $\mathrm{Cd}$ and $\mathrm{Cu}$. The final $\mathrm{pH}$ in the 2 compartment cell experiments was about $2 \mathrm{pH}$ units lower than in the 3 compartment cell, so this suggests a different metal speciation. Compared to the 3 compartment cell results, it suggests that the predominant speciation of $\mathrm{Cd}, \mathrm{Cu}$ and $\mathrm{Zn}$ is cationic and cations cannot be removed in the 2 compartment cell.

In the experiments with the APC residue a high $\mathrm{Pb}$ removal $(22-66 \%)$ was achieved. $\mathrm{The} \mathrm{Pb}$ removal was generally higher in the 3 compartment cell, than in the 2 compartment cell. The amount of $\mathrm{Pb}$ in the liquid suspension after the experiments with the 2 compartment cell was close to zero, meaning that there was no uncharged or negatively charged $\mathrm{Pb}$ species that could not be removed in this cell setup. A higher $\mathrm{Pb}$ removal was obtained in the SD-2-0.1-14D experiment, in which the resulting $\mathrm{pH}$ was higher than in experiment SD-2-1-14D. The higher $\mathrm{pH}$ might be the reason for higher removal as $\mathrm{Pb}$ is amphoteric and soluble at very high $\mathrm{pH}$ and at low $\mathrm{pH}$. Previous $\mathrm{pH}$ dependent desorption experiments with the APC residue showed immobilization of $\mathrm{Pb}$ in the $\mathrm{pH}$ range 6-11 [24].

Even though the removal was highest in the experiments with 14 days duration, the final heavy metal concentrations in the treated MSWI residues (results not shown) were higher or similar to the initial concentrations in Table 2. This is due to a significant dissolution of the residue; $13-27 \%$ for the fly ash and $19-65 \%$ for the APC residue during the experiments, highly dependent on the $\mathrm{pH}$ of the suspensions. According to Lima et al. [25] the removal of heavy metals from MSWI residues should also be assessed in relation to the leachability of the heavy metals, especially if the treated ash should be reused [7].

\subsection{Heavy metal leaching}


The heavy metal leaching before and after the electrodialytic experiments in relation to $\mathrm{pH}$ measured in the leachate is shown in Fig. 4, along with limiting values $\mathrm{C} 1$ and $\mathrm{C} 3$.

The results showed significantly reduced leaching of heavy metals from ED treated fly ash, even with higher total heavy metal content. The leaching level was significantly different between the two MSWI residues after the electrodialytic treatment. The only similar patterns were increased leaching of $\mathrm{Cr}$ and reduced leaching of $\mathrm{Pb}$ in all the experiments. In this study, it was not investigated whether $\mathrm{Cr}$ was present as $\mathrm{Cr}$ (IV) or $\mathrm{Cr}$ (III), but it is important to include its speciation in future studies. However, even if $\mathrm{Cr}$ leaching increased, studies of reusing EDR treated APC residue in mortar has shown that $\mathrm{Cr}$ leaching from mortar with cement replacement by EDR treated APC residue is at a similar level as reference mortar without APC residue [7]. For Cd, the leaching increased from the fly ash after EDR treatment, although remaining below limiting values if $\mathrm{pH}$ is not reduced below 10; while for the APC residue, the leaching value was below the detection limit for most of the experiments. $\mathrm{Cu}$ leaching was below $\mathrm{C} 3$ before and after all experiments. Increased leaching of $\mathrm{Zn}$ was observed after experiments reaching $\mathrm{pH}$ below 8 in the experiments with fly ash. The highest heavy metal removal rates were obtained at the lowest $\mathrm{pH}$, but lower $\mathrm{pH}$ resulted in higher leaching values.

The leaching limiting value C3 was successfully met for all heavy metals in some of the experiments meaning that, in what regards leaching, the treated residues could be utilized in construction materials. For the fly ash, these C3 values were met for experiments except W-2-17D, W-3-1-14D, W-3-0.1-14D and W-3-1-14D. The leachate $\mathrm{pH}$ was between 10.2-11.5 when the C3 values were met. For the APC residue the C3 values for heavy metal leaching was only met in one experiment (SD-3-0.1-14D) at leachate $\mathrm{pH}$ 10.5. As the $\mathrm{pH}$ decrease was faster in the 2 compartment cell, especially for the fly ash (Fig. 2) the remediation times could possibly be shorter to achieve the desired $\mathrm{pH}$ range. This would reduce costs even further for upscaling and making the 2 compartment EDR method an eligible remediation method for fly ash.

\subsection{Chloride}

The concentration of leached chloride after the electrodialytic experiments is shown in Fig. 5, together with the $\mathrm{C} 1$ and $\mathrm{C} 3$ values for chloride. Contrarily to the heavy metals, chloride leaching is not $\mathrm{pH}$ dependent but availability controlled [26]. The chloride leaching was significantly reduced in all the electrodialytic experiments for both the MSWI residue types and for both cell types. For 
the fly ash, which had the lowest chloride content, the chloride leaching was reduced to below C3 in all experiments, which means that for four experiments, the measured heavy metal and chloride leaching levels complied with the regulative limits $\mathrm{C} 3$. The $\mathrm{Cl}$ limiting value for $\mathrm{C} 3$ was fulfilled for two of the experiments (SD-3-1-7D and SD-3-1-14 D) with the APC residue, but the heavy metal leaching was not below the limit for these two experiments.

For $\mathrm{Cl}$ leaching there seems to be a difference between the two cell types, with generally lower final leaching of $\mathrm{Cl}$ from the residues when using the 3 compartment cell. The amount of $\mathrm{Cl}$ in the suspension liquid at the end of the ED experiments was higher in the experiments with the APC residue than with the fly ash (results not shown). There was a general tendency for a higher amount of $\mathrm{Cl}$ in the suspensions with the 2 compartment cell, which means that the oxidation of chloride directly at the anode is not as efficient as electromigration for removal of $\mathrm{Cl}$ from the suspension.

The main speciation for $\mathrm{Cl}$ in $\mathrm{APC}$ residues is halite $(\mathrm{NaCl})$, sylvite $(\mathrm{KCl})$ and calcium hydroxychloride $(\mathrm{CaOHCl})$, where the two former are easily soluble minerals and the latter is easily soluble condensate on fly ash surface particles [24]. These minerals were also identified in the APC residue of the present investigation (Fig. 3). The main $\mathrm{Cl}$ minerals for the fly ash were $\mathrm{NaCl}$ and $\mathrm{KCl}$. It was found that these phases were removed after electrodialytic treatment in both the 2 and

the 3 compartment cells and from both MSWI residues, which was also expected according to other studies [7, 12]. Since $\mathrm{Cl}$ leaching is availability controlled, increased remediation time would increase the $\mathrm{Cl}$ removal and thus $\mathrm{Cl}$ decrease leaching, which is also indicated by the results of this study (Fig. 5).

\section{Conclusion}

- The removal percentages for heavy metals were generally low for both MSWI residues, except for up to $61 \% \mathrm{Cd}$ and $53 \% \mathrm{Zn}$ from the fly ash and $66 \% \mathrm{~Pb}$ from the APC residue after 14 days of remediation in the 3 compartment cell.

- The new 2 compartment cell did not positively affect the heavy metal removal. Electrodialytic remediation with the 3 compartment cell could be a method to selectively remove $\mathrm{Cd}$ and $\mathrm{Zn}$ from fly ash and $\mathrm{Pb}$ from $\mathrm{APC}$ residue, to possibly extract these metals from the respective residues and process the metals for reuse. 
- The leaching concentrations of $\mathrm{Cd}, \mathrm{Cu}, \mathrm{Pb}$ and $\mathrm{Zn}$ generally decreased in all the electrodialytic experiments. Contrarily, $\mathrm{Cr}$ leaching increased after all the electodialytic experiments and the reasons for this need further investigations.

- The most important factor for both the heavy metal removal and leaching after electrodialytic remediation is the final $\mathrm{pH}$ of the MSWI residue. For the fly ash the optimum $\mathrm{pH}$ range is $\mathrm{pH}$ 10.2-11.5, which could be achieved within 3 days of remediation. Whereas the APC residue shows to be much more susceptible towards small changes in $\mathrm{pH}$, which result in higher leaching, with the lowest leaching results at $\mathrm{pH} 10.5$ achieved after 14 days of remediation.

- It is possible to reach below the Danish leaching limiting values for possible reuse for $\mathrm{Cd}$, $\mathrm{Cu}, \mathrm{Cr}, \mathrm{Pb}$ and $\mathrm{Zn}$ when applying electrodialytic remediation to the MSWI residues using the 3 compartment cell. For the fly ash, $\mathrm{Cl}$ leaching also reaches below the leaching limit.

- The $\mathrm{Cl}$ removal is not higher when using the 2 compartment cell compared to the 3 compartment cell. Also higher concentrations of $\mathrm{Cl}$ are present in the liquid in the suspension compartment when using the 2 compartment cell.

- The fly ash shows higher potential for reuse after electrodialytic remediation than the APC residue. A separation of fly ash before adding the air pollution control products such as lime and activated carbon could be recommended to produce a particulate residue fraction that could be more suitable for reuse after electrodialytic remediation.

\section{Acknowledgements}

The project FP7-PEOPLE-2010-IRSES-269289-ELECTROACROSS - Electrokinetics across disciplines and continents: an integrated approach to finding new strategies for sustainable development and DTU GAP funding from Copenhagen Cleantech Clusters are acknowledged for financing the study. Laboratory technicians Sabrina June Hvid and Carolyn Skovby are thanked for sample analysis.

\section{References}

[1] M. J. Quina, J. C. Bordado, R. M. Quinta-Ferreira, Treatment and use of air pollution control residues from MSW incineration: An overview, Waste Management, 28 (2008) 2097.

[2] T. R. Sun, L. M. Ottosen, P. E. Jensen, G. M. Kirkelund, Electrodialytic remediation of suspended soil - Comparison of two different soil fraction, Journal of Hazardous Materials, 203-204 (2011) 229. 
[3] G.M. Kirkelund, L.M. Ottosen, A. Villumsen, Electrodialytic remediation of harbour sediment in suspension - evaluation of effects induced by changes in stirring velocity and current density on heavy metal removal and pH, Journal of Hazardous Materials, 169 (2009) 685.

[4] M. Pazos, G.M. Kirkelund, L. M. Ottosen, Electrodialytic treatment for metal removal from sewage sludge ash from fluidized bed combustion, Journal of Hazardous Materials, 176 (2010) 1073.

[5] G.M. Kirkelund, A.J. Damoe, L.M. Ottosen, Electrodialytic removal of Cd from biomass combustion fly ash suspensions, Journal of Hazardous Materials 250-251 (2013) 212.

[6] C. D. Ferreira, P. Jensen, L. Ottosen, A. Ribeiro, Preliminary Treatment of MSW Fly Ash as a Way of Improving Electrodialytic Remediation, Journal of Environmental Science and Health, Part A. vol. 43, No.8 (2008) 837.

[7] G.M. Kirkelund, M.R. Geiker, P.E. Jensen, Electrodialytically treated MSWI APC residue as substitute for cement in mortar, Nordic Concrete Research, 49 (1) (2014) 1.

[8] A. J. Pedersen, Electrodialytic removal of heavy metals from fly ashes, Ph.D. Thesis, Technical University of Denmark, Denmark (2002).

[9] A.J. Pedersen, Evaluation of assisting agents for electrodialytic removal of $\mathrm{Cd}, \mathrm{Pb}, \mathrm{Zn}, \mathrm{Cu}$ and Cr from MSWI fly ash, Journal of Hazardous Materials, B95 (2002) 185.

[10] A.J. Pedersen, L.M. Ottosen, A. Villumsen, Electrodialytic removal of heavy metals from municipal solid waste incineration fly ash using ammonium citrate as assisiting agent, Journal of Hazardous Materials, B122 (2005) 103.

[11] C. Ferreira, P. Jensen, L. Ottosen, A. Ribeiro, Removal of selected heavy metals from MSW fly ash by the electrodialytic process, Engineering Geology, 77 (2005) 333.

[12] A.J. Pedersen, K.H. Gardner, Characterization of municipal solid waste incineration fly ash before and after electrodialytic remediation, J Phys IV France, 107 (2003) 1029.

[13] L.M. Ottosen, H.K. Hansen, C.B. Hansen, Water splitting at ion-exchange membranes and potential differences in soil during electrodialytic soil remediation, J. Appl. Electrochem. 30 (2000) 1199.

[14] G.M. Nystroem, L.M. Ottosen, A. Villumsen, Acidification of harbor sediment and removal of heavy metals induced by water splitting in electrodialytic remediation, Sep. Sci. Technol. 40 (2005) 2245. 
[15] L.M. Ottosen, A.T. Lima, A.J. Pedersen, A.B. Ribeiro, Electrodialytic extraction of $\mathrm{Cu}, \mathrm{Pb}$ and $\mathrm{Cl}$ from municipal solid waste incineration fly ash suspended in water, J Chem Technol Biotechnol, 81 (2006) 553.

[16] L.M. Ottosen, P.E. Jensen, G.M. Kirkelund, B. Ebbers, Electrodialytic recovery and purification of phosphorous from sewage sludge ash, sewage sludge and wastewater, PCT/EP2014/068956.

[17] B. Ebbers, L.M. Ottosen, P.E. Jensen, Comparison of two different electrodialytic cells for separation of phosphorus and heavy metals from sewage sludge ash, Chemosphere, 125 (2015) 122. [18] DS 259 "Determination of metals in water, sludge and sediments - General guidelines for determination by atomic absorption spectrophotometry in flame”, 2003.

[19] DS/EN 12457-3, "Characterisation of waste - Leaching - Compliance test for leaching of granular waste materials and sludges - Part 3: Two stage batch test at a liquid to solid ratio of $21 / \mathrm{kg}$ and $81 / \mathrm{kg}$ for materials with high solid content and with particle size below $4 \mathrm{~mm}$ (without or with sizereduction)", 2002.

[20] DS239, "Chloride - Potentiometric method", 1984.

[21] Danish Ministry of the Environment, Bekendtgørelse om genanvendelse af restprodukter og jord til bygge- og anlægsarbejder BEK nr 1480 af 12/12/2007 (2007) (in Danish).

[22] T.R.Sun, L.M. Ottosen, P.E. Jensen, G.M. Kirkelund, Effect of pulse current on acidification and removal of $\mathrm{Cu}, \mathrm{Cd}$ and As during suspended electrodialytic soil remediation, Electrochimica Acta, 107 (2013) 187.

[23] P.E. Jensen, L.M. Ottosen, C. Ferreira, Kinetics of Electrodialytic Extraction of Pb and Soil Cations from Contaminated Soil Fines in Suspension, Journal of Hazardous Materials, 138(3), (2006) 493.

[24] G.M. Kirkelund, P.E. Jensen, A. Villumsen, L.M. Ottosen, Test of electrodialytic upgrading of MSWI APC residue in pilot scale: focus on reduced metal and salt leaching, Journal of Applied Electrochemistry, 40 (2010) 1049.

[25] A.T. Lima, L.M. Ottosen, A.B. Ribeiro, Assessing fly ash treatment: Remediation and stabilization of heavy metals, Journal of Environmental Management, 95 (2012) S110.

[26] M.J. Quina, J.C. Bordado, R.M. Quinta-Ferreira, The influence of $\mathrm{pH}$ on the leaching behaviorof inorganic components from municipal solid waste APC residues, Waste Management, 29 (2009) 
2483. 


\section{Table 1}

Experimental conditions for electrodialytic experiments. (W/SD-X-Y-ZD, where W - fly ash, SD- APC residue, X cell type, 2 or 3 compartment cell, $\mathrm{Y}$ - current density (mA/ $\left.\mathrm{cm}^{2}\right)$ and $\mathrm{ZD}$ - duration in days).

\begin{tabular}{lcccc}
\hline Experiment & MSWI residue & Cell type & Current density $\mathbf{( m A / \mathbf { c m } ^ { 2 } )}$ & Duration (days) \\
\hline W-2-0.1-ZD & Fly ash & 2 & 0.1 & $3,7,14$ \\
W-3-0.1-ZD & Fly ash & 3 & 0.1 & $3,7,14$ \\
W-2-1-ZD & Fly ash & 2 & 1.0 & $3,7,14$ \\
W-3-1-ZD & Fly ash & 3 & 1.0 & $3,7,14$ \\
SD-2-0.1-ZD & APC residue & 2 & 0.1 & $3,7,14$ \\
SD-3-0.1-ZD & APC residue & 3 & 0.1 & $3,7,14$ \\
SD-2-1-ZD & APC residue & 2 & 1.0 & $3,7,14$ \\
SD-3-1-ZD & APC residue & 3 & 1.0 & $3,7,14$ \\
\hline
\end{tabular}


Table 2

Characteristics of fly ash and APC residue (mean values \pm standard error).

\begin{tabular}{|c|c|c|c|c|c|}
\hline \multirow[t]{2}{*}{ Parameter } & \multicolumn{2}{|c|}{ MSWI residue } & & & \multirow[b]{2}{*}{$\begin{array}{l}\text { Statistical } \\
\text { difference }\end{array}$} \\
\hline & Fly ash $(W)$ & APC residue (SD) & & & \\
\hline $\mathrm{pH}_{\mathrm{KCl}}(\mathrm{L} / \mathrm{S}=2.5)$ & 12.4 & 12.2 & & & $\mathrm{a}$ \\
\hline Conductivity $\left(\mathrm{mS} \mathrm{cm}^{-1}\right)$ & $55.33 \pm 1.11$ & $75.24 \pm 1.82$ & & & a \\
\hline Water content (\%) & $0.36 \pm 0.00$ & $0.87 \pm 0.25$ & & & - \\
\hline Water solubility (\%) & $0.76 \pm 0.06$ & $0.66 \pm 0.06$ & & & - \\
\hline Loss on ignition (\%) & $0.76 \pm 0.14$ & $4.07 \pm 0.04$ & & & a \\
\hline Carbonate content (\%) & $8.37 \pm 0.06$ & $14.55 \pm 0.12$ & & & $\mathrm{a}$ \\
\hline $\mathrm{Cd}\left(\mathrm{mg} \mathrm{kg}^{-1}\right)$ & $97.6 \pm 0.4$ & $88.7 \pm 2.0$ & & & $\mathrm{~b}$ \\
\hline $\mathrm{Cr}\left(\mathrm{mg} \mathrm{kg}^{-1}\right)$ & $99.0 \pm 1.1$ & $73.1 \pm 0.9$ & & & $\mathrm{a}$ \\
\hline $\mathrm{Cu}\left(\mathrm{mg} \mathrm{kg}^{-1}\right)$ & $749.1 \pm 7.0$ & $551.2 \pm 20.7$ & & & $\mathrm{a}$ \\
\hline $\mathrm{Pb}\left(\mathrm{g} \mathrm{kg}^{-1}\right)$ & $2,710 \pm 300$ & $3,110 \pm 110$ & & & - \\
\hline $\mathrm{Zn}\left(\mathrm{g} \mathrm{kg}^{-1}\right)$ & $22,400 \pm 410$ & $19,440 \pm 370$ & & & $\mathrm{a}$ \\
\hline \multirow{2}{*}{$\begin{array}{l}\text { Leaching } \\
p H\end{array}$} & & & C1 [21] & C3 [21] & \\
\hline & 12.4 & 11.8 & & & \\
\hline $\mathrm{Cd}\left(\mathrm{mg} \mathrm{L}^{-1}\right)$ & n.d. & n.d. & 0.002 & 0.04 & - \\
\hline $\mathrm{Cr}\left(\mathrm{mg} \mathrm{L}^{-1}\right)$ & $0.02 \pm 0.00$ & $0.03 \pm 0.00$ & 0.01 & 0.5 & - \\
\hline $\mathrm{Cu}\left(\mathrm{mg} \mathrm{L}^{-1}\right)$ & $0.01 \pm 0.00$ & $0.27 \pm 0.02$ & 0.045 & 2 & $\mathrm{a}$ \\
\hline $\mathrm{Pb}\left(\mathrm{mg} \mathrm{L}^{-1}\right)$ & $41.9 \pm 2.3$ & $450.0 \pm 9.6$ & 0.01 & 0.1 & $\mathrm{a}$ \\
\hline $\mathrm{Zn}\left(\mathrm{mg} \mathrm{L}^{-1}\right)$ & $2.41 \pm 0.23$ & $12.70 \pm 0.39$ & 0.1 & 1.5 & $\mathrm{a}$ \\
\hline $\mathrm{Cl}^{-}\left(\mathrm{mg} \mathrm{L}^{-1}\right)$ & $12,100 \pm 180$ & $25,600 \pm 150$ & 150 & 3,000 & $\mathrm{a}$ \\
\hline
\end{tabular}

n.d. not detected, ${ }^{\text {a }}$ Significantly different $(\mathrm{p}<0.01),{ }^{\mathrm{b}}$ Significantly different $(\mathrm{p}<0.05)$ 
Table 3

Removal and distribution of heavy metals in the 14 days experiments.

\begin{tabular}{|c|c|c|c|c|c|c|c|c|c|c|c|c|c|c|c|c|}
\hline & \multirow[b]{2}{*}{$\begin{array}{l}\text { Final } \\
\text { pH * }\end{array}$} & \multicolumn{5}{|c|}{ Removal (\%) } & \multicolumn{5}{|c|}{ To anode side of total removal (\%) } & \multicolumn{5}{|c|}{ In liquid suspension (\%) } \\
\hline & & Cd & $\mathrm{Cr}$ & $\mathrm{Cu}$ & $\mathbf{P b}$ & Zn & Cd & $\mathrm{Cr}$ & $\mathrm{Cu}$ & $\mathbf{P b}$ & Zn & Cd & $\mathrm{Cr}$ & $\mathrm{Cu}$ & $\mathbf{P b}$ & Zn \\
\hline W-3-0.1 & 10.6 & 3.0 & 4.5 & 1.5 & 1.3 & 2.0 & 94 & 88 & 41 & 84 & 43 & 0 & 0.7 & 0 & 0 & 0 \\
\hline W-2-0.1 & 10.6 & 1.1 & 3.8 & 3.8 & 0.9 & 1.5 & - & - & - & - & - & 0.1 & 7.7 & 0.5 & 0 & 0 \\
\hline W-3-1 & 8.2 & 61 & 1.1 & 3.3 & 2.5 & 53 & 7.3 & 61 & 9.4 & 7.0 & 1.4 & 13 & 0 & 0.8 & 0.2 & 13 \\
\hline W-2-1 & 6.4 & 56 & 3.8 & 15 & 0.5 & 4.6 & - & - & - & - & - & 28 & 7.0 & 15 & 0.2 & 39 \\
\hline SD-3-0.1 & 11.7 & 5.2 & 4.5 & 1.7 & 30 & 0.8 & 74 & 80 & 38 & 52 & 34 & 2.2 & 1.5 & 0 & 0 & 0 \\
\hline SD-2-0.1 & 12.8 & 0.3 & 0.3 & 0.5 & 45 & 0.5 & - & - & - & - & - & 0 & 0.2 & 0 & 0 & 0 \\
\hline SD-3-1 & 10.1 & 0.4 & 2.4 & 1.3 & 66 & 0.5 & 89 & 67 & 35 & 3.7 & 35 & 0 & 2 & 0 & 0 & 0 \\
\hline SD-2-1 & 10.9 & 0.8 & 1.4 & 0.4 & 22 & 0.3 & - & - & - & - & - & 0 & 19 & 0 & 0 & 0 \\
\hline
\end{tabular}

$* \mathrm{pH}$ measured on dry residue 


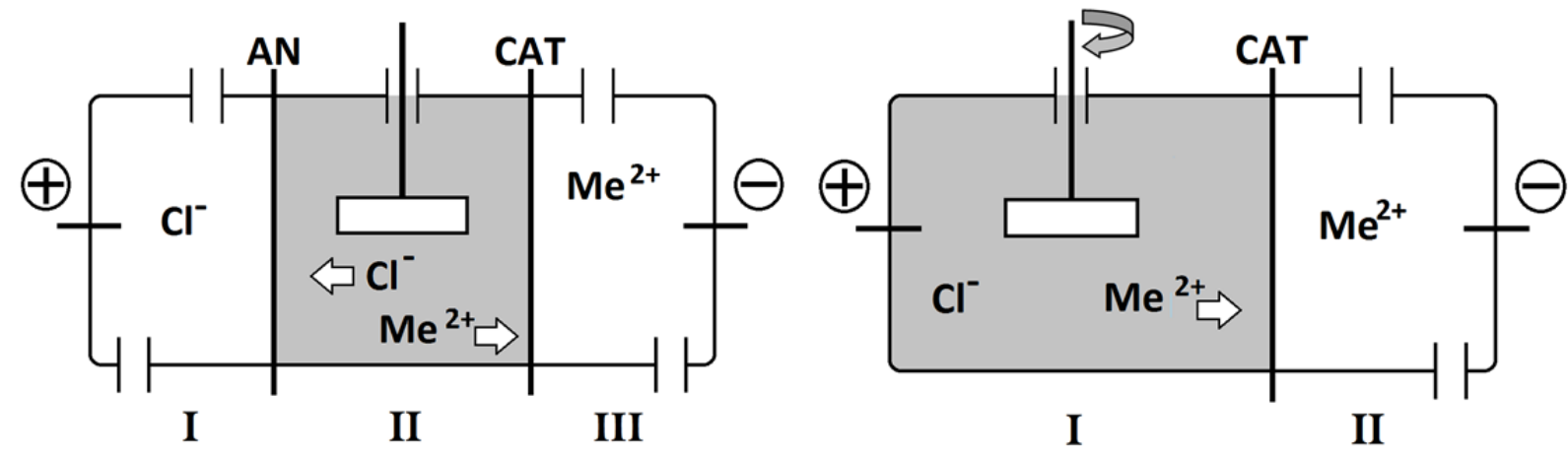

a

b

Fig.1. The experimental set-up of the 3 and 2 compartment electrodialytic cell. AN-anion exchange membrane, CAT-cation exchange membrane. 

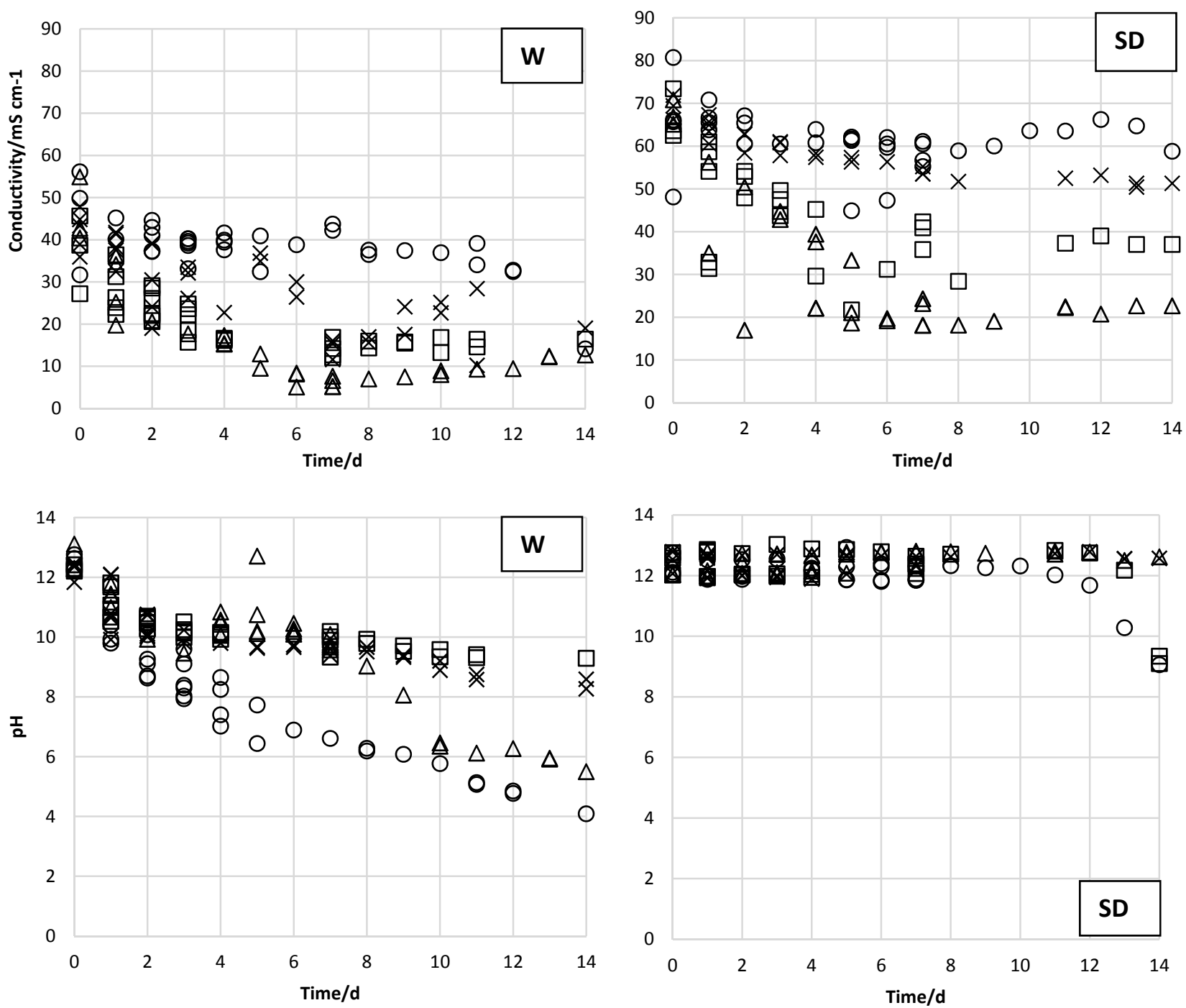

$\times \mathrm{W} / \mathrm{SD}-2-0.1 \quad$ OW/SD-2-1.0 $\quad \square \mathrm{W} / \mathrm{SD}-3-0.1 \quad \Delta \mathrm{W} / \mathrm{SD}-3-1.0$

Fig. 2. $\mathrm{pH}$ and electrical conductivity in the ash suspensions during the electrodialytic experiments, $\mathrm{W}$-wet fly ash, SD-semidry APC residue. 

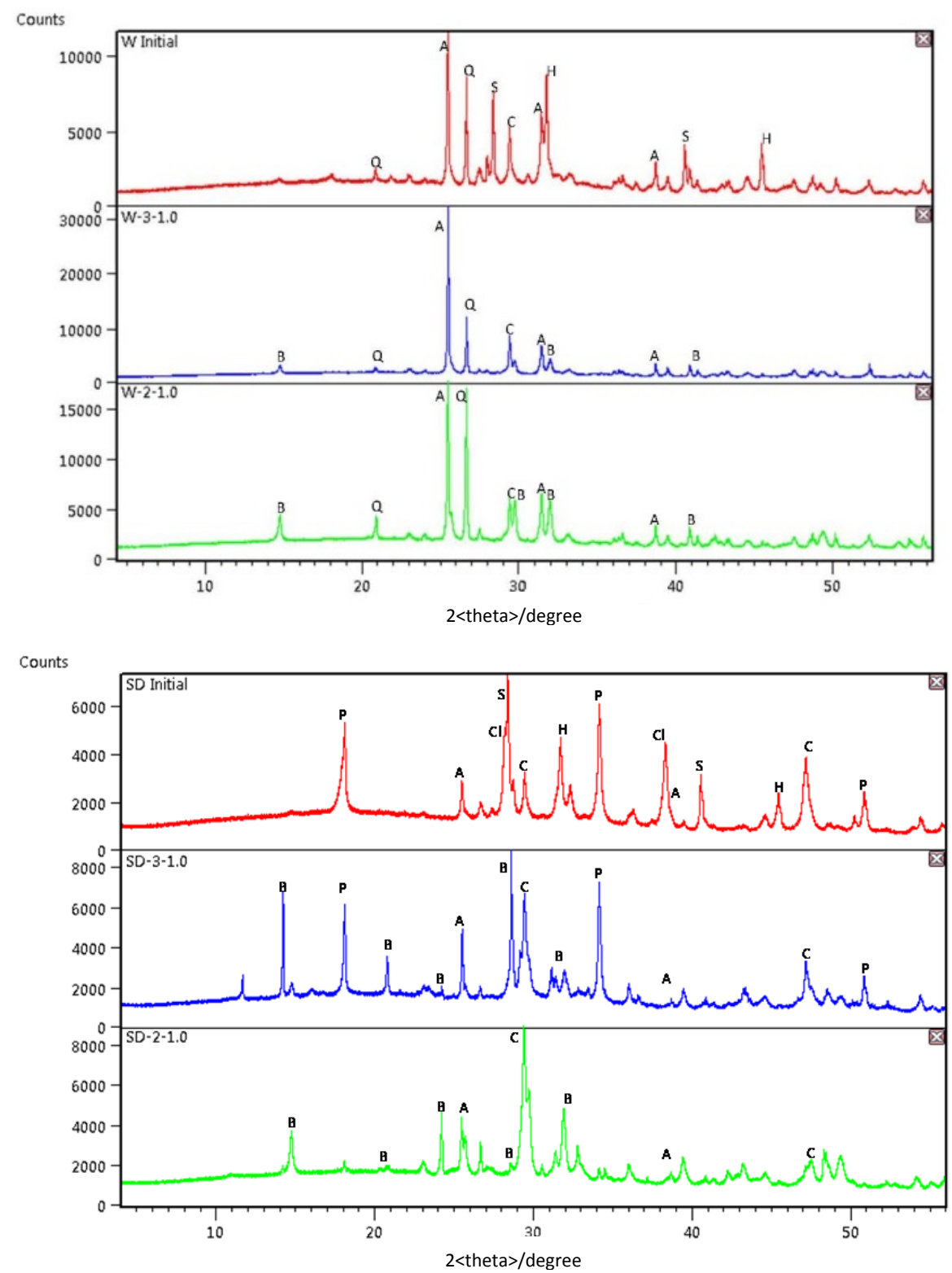

Fig. 3. XRD diffractograms of initial and EDR treated MSWI residues, 7 days experiments. Q-Quartz, A anhydrite, S-sylvite, C- carbonate, H- halite, B - bassanite, Cl- Calcium hydroxychloride. 
Fly ash
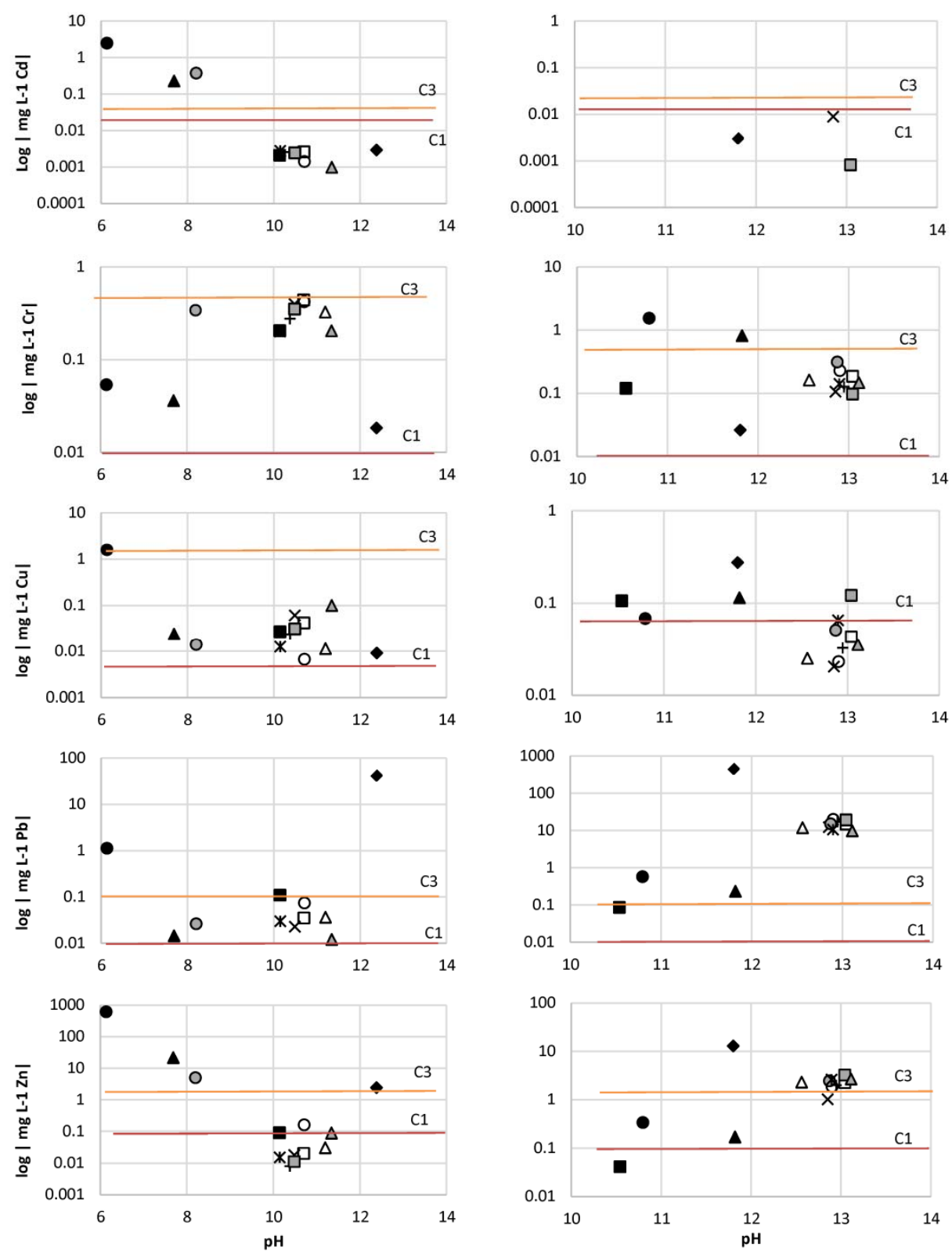

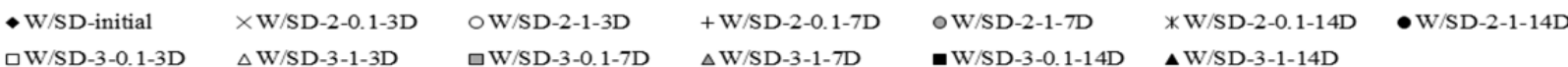

Fig. 4. Leaching of heavy metals before and after electrodialytic remediation 


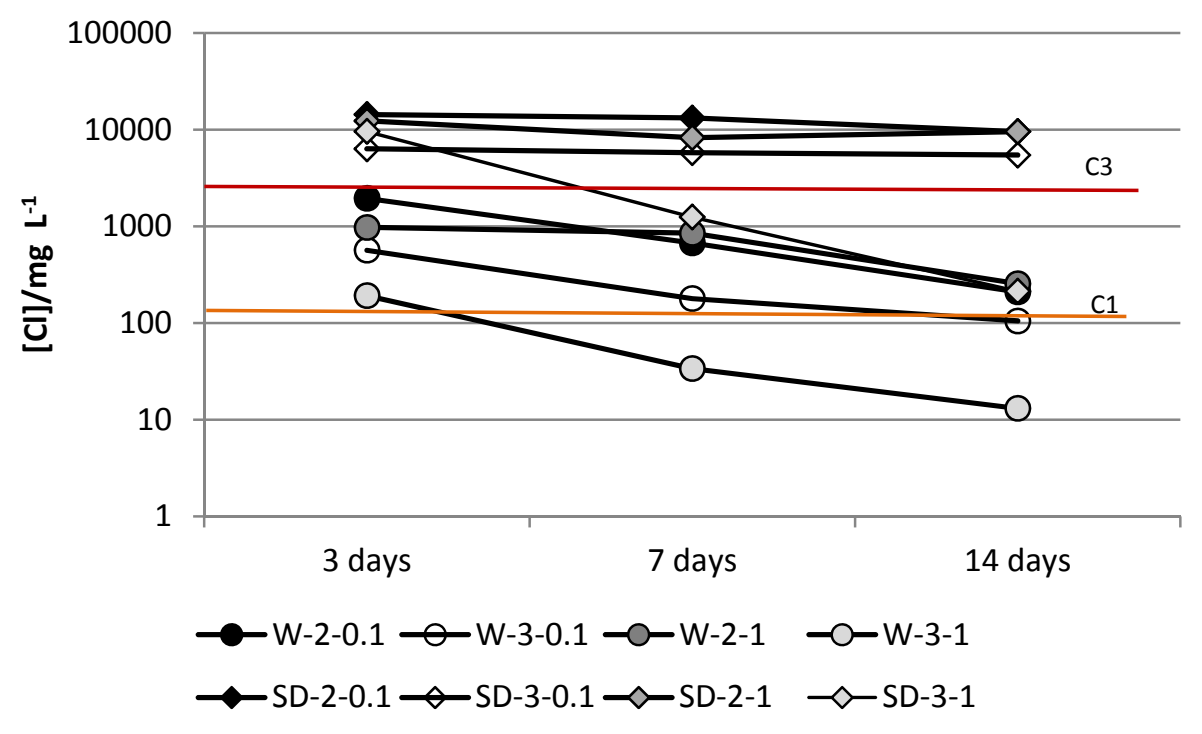

Fig. 5. Chloride leaching in the MSWI residues after the ED experiments. 